\title{
Islands "Smart Energy" for eco-sustainable energy a case study "Favignana Island"
}

\author{
Giuseppe Cannistraro $^{1 *}$, Mauro Cannistraro ${ }^{2}$, GaetanoTrovato $^{3}$ \\ ${ }^{1}$ Department of Engineering of Messina University of Messina, Messina 98121, Italy \\ ${ }^{2}$ University of Ferrara, School of Architecture, Ferrara 40122, Italy \\ ${ }^{3}$ Architect, Freelancer, Messina 98121, Italy
}

Email: gcannistraro@unime.it

\begin{abstract}
The term "Smart" in the last decade has often flanked other words to express a new and intelligent way of living in a modern society where you cannot separate the two synergic aspects: Energy and Sustainability. These latter two aspects flow into the new way of managing an isolated territory that often presents difficulties because of no interactions with the surrounding area; to remedy these difficulties has been developed in recent years the "Smart-Island" project, which involves many European countries and several sponsors. The concept of "SmartIsland" defines a way of life in an isolated environment, such as that of these islands, can solve independently, with the use of renewable and sustainable sources the energy needs of the island, with some projects that take into account the preservation and the wealth of the territory. In this paper, after a brief review of what has been proposed in some islands of the world, it will develop a case study, represented by the island of Favignana, which has particular characteristics in relation to its energy dependence.
\end{abstract}

Keywords: Sustainable Energy, Photovoltaic, Wind Power, Energy Swell, Water Resources.

\section{INTRODUCTION}

The development of the islands is greatly dependent on energy resources from the problem of environmental pollution, it is therefore necessary to provide and implement a real energy-environmental strategy, which is able to address and resolve the two issues. The term "Smart" in the last decade has often flanked high words to express a new and intelligent way of living in a modern society. In the micro world, the term "smart" was applied in the materials fields, "smart materials", and of micro-sensors, technologies, facilities, etc, and then extend it in the macro world, the concept of "smart city," which contains within the concept of smart, in the following areas: governance, mobility, sustainability, energy etc. The Smart City is a new city model that brings together a coordinated set of strategies that aim to make the city more sustainable in terms of environmental energy and social. The energy needs and the eco-sustainability are two concepts that flow into the new way of managing an isolated territory that often presents difficulties because of no interactions with the surrounding area, to resolve these difficulties has been developed the concept of "Smart- Island ".

This concept expected a new way of living in an isolated environment, where, thanks to projects that using renewable sources, it can get a sustainable living, in the energy independence, with respect and preservation of the land; these problems often are not solved in the isolated territories. In this work, it we explain a brief overview of what has been done in some parts of the world, and we will be also developed a case study, represented by the island of Favignana, which has energetic peculiar characteristics.

\section{THE "SMART ISLANDS" IN EUROPE}

The European Union for the period 2014-2020, in its means of implementation, in the next Framework Program for Research and Innovation Horizon 2020 provides for a general Community strategy on urban areas (Urban Europe Joint Programming Initiative), which introduces the innovative concept of " Smart Cities ".

In Athens on $21^{\text {th }}$ and $22^{\text {th }}$ June 2016 has witnessed the birth of the first European forum on the "Smart" islands. The main topics were: energy, transport, mobility, waste, and water issue.

All resources used appropriately can be an opportunity for small islands not artificially connected to the mainland.

The islands should be considered experimental laboratories of innovative solutions for environmental sustainability, which exploits the available renewable energy. The European Chambers of Commerce, drew up some practical proposals for the definition of a concept of "Smart Island" that can help the development of these areas do not always favored 
economically. A "Smart City" is represented by a single complex system consists of the following ecosystems: land, energy, transport, construction, waste management, use of water resources, industrial man ufacturing base, agriculture, services, tourism, economic, financial, social, employment and cultural.

In a meeting held in Croatia, the working group has identified four priority areas for action:

- energy self-sufficiency, to ensure the transition from conventional hybrid energy sources to those totally renewable;

- sustainability that encourages the proper development of the agricultural sector can guarantee the demand from the different territories in order to avoid an insular entrepreneurship based solely on tourism and hospitality;

- the transport as a public-private investment in mobility, promoting eco forms of transport;

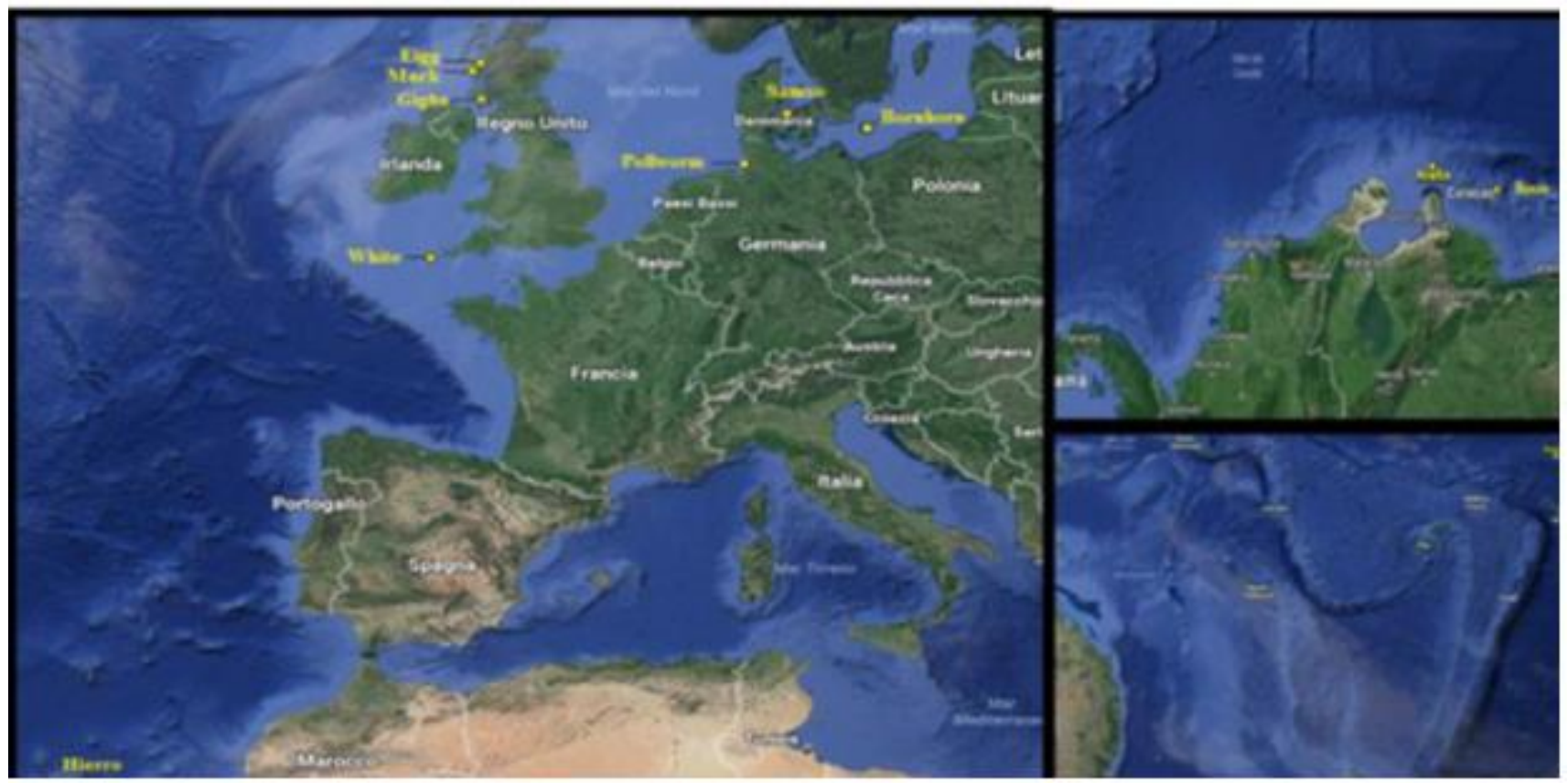

Figure 1. The 11 "Smart Islands" European

\subsection{El Hierro island}

The Spanish island of "El Hierro", located in the Canary Islands, from the 2014 to produces electricity, it has available a system of hydroelectric plants, composed of two water reservoirs with capacity of 700 thousand $\mathrm{m}^{3}$, at vertical drop of $682 \mathrm{~m}$ and a pumping station $6 \mathrm{MW}$.

A wind power plant, consists of 5 integrated turbines at above hydroelectric plant, is installed to bring the total power at the value of 11.5 MW (see Fig.2).

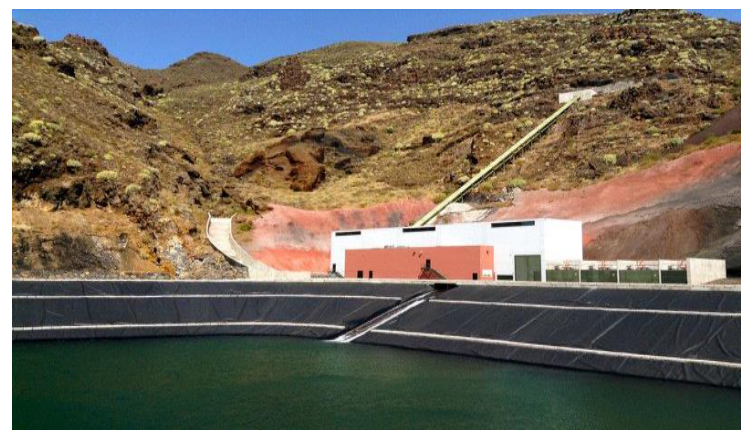

Figure 2. Basin received hydroelectric plant

The electricity is generated by hydraulic turbines driven by the passage of water and in a continuous manner from wind turbines that use the trade winds always present in the archipelago.

-the development of strategies and integrated sector policies to support the introduction of digital technologies, a greater investment on health issues and a revaluation of the islands within the European cohesion policy.

In the northern Europe, some companies are very forward in the exploitation of renewable energy, in the recycling and reusing of waste.

Many examples to achieve energy independence through the use of renewable energies of "Smart Island" are observable in Europe [1-11].

In the Fig. 1 are shown the "11 Smart Islands" in Europe that have achieved significant results in terms of their energy independence.

This system allows to save up over 1.8 million euro per year of petroleum, corresponding to the cost of about 40 thousand barrels of petroleum consumed by the old power plant, and to not put into the atmosphere up 18,700 tons of $\mathrm{CO}_{2}$

The construction of the plant, it took 5 years of work and an investment of $65 \mathrm{mln}$ euro.

It was decided to not scrapped the pre-existing thermal power plant, to cope with its $12.7 \mathrm{MW}$ of capacity, in cases of exceptional demand peaks.

The municipal and partners are studying a system of electric mobility for the whole island which since 2000 has been recognized by UNESCO 'Biosphere Reserve'

\subsection{The Samso Island and Bornholm in Denmark}

The island of "Samso" about $150 \mathrm{~km}$ from Copenhagen, has created a system of renewable energy plants, which made the island, energetically independent. 
The plant consists of 11 wind turbines, 10 onshore and one offshore. In this configuration, the plant is able to offset the carbon emissions of the transport sector including cars, ferries and farm equipment, for a total of $34 \mathrm{MW}$.

The wind turbine system helps to reduce the emission of about 12 tonnes of $\mathrm{CO}_{2}$ per capita considering that each MW covers the needs of about 630 homes.

A network of district heating cost 2.5 million euro, was created in 2005 with the participation of 240 families.

The network is composed of four plants, three of which are fed with a straw from agriculture and wood waste of local forests, supplemented by solar panels for the preheating the water.

- The Island of Bornholm covers over 50\% of their electricity requirements using plants that use renewable sources of wind type and biomass, consisting of wood chips from forest waste and straw from agriculture (see Figure 3).

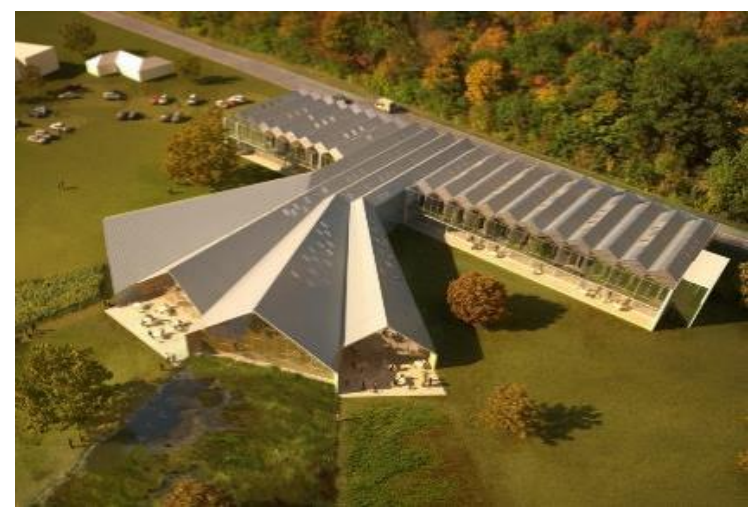

Figure 3. Plant to wood waste in the Bornholm Island

- Currently it is connected to the Swedish electricity network by a submarine cable triphasic of $60 \mathrm{kV} \mathrm{AC}$, which is among the alternating current cable longest in Europe.

The aim is to achieve total independence from coal combustion in the 2025 .

The 29,000 users corresponding to 43,000 inhabitants, they see met the energy demand, with a $55 \mathrm{MW}$ peak daily, in one of the most advanced systems in the world of smart grid. The system comprises a mix of energy resources, with low-carbon consisting of: 35 wind turbines for a total of $30 \mathrm{MW}, 16 \mathrm{MW}$ from cogeneration plants to biomass, from $1.5 \mathrm{MW}$ photovoltaic plant, and numerous electric vehicles consist of ecological public bus for a sustainable mobility.

\subsection{The Islands "Eigg-Gigha and" Muck "in Scotland and "White" in Britain}

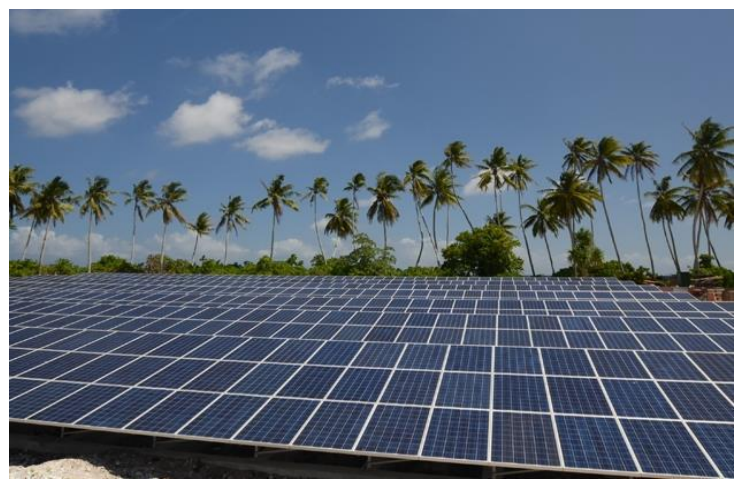

Figure 4. Photovoltaic systems
-The Island "Eigg" is now a reality energetically selfsufficient, its energy potential is represented by renewable sources, such as wind, sun and water, of which the island is rich. The energy self-sufficiency of the 45 families is obtained thanks to the systems from renewable sources present on the island, from which we get $5 \mathrm{~kW}$ daily of electricity imposed for the inhabitants and $10 \mathrm{~kW}$ for the 20 industrial enterprises.

In 2008, it was inaugurated over $11 \mathrm{~km}$ of the island's independent electric power grid, at a cost of 1.9 million euro and in support of renewable sources (see Figure 4).

The system is constituted by: 3 hydroelectric plants, the largest is about of $100 \mathrm{~kW}$ and it is located in the western part of the island and the other two are smaller about 5-6 kW; there are also 4 wind turbines of $6 \mathrm{~kW} ; 50 \mathrm{~kW}$ of photovoltaic panels.

The right balance of these three different types of sources makes sure the electricity needs of the island also in the moments in which not all can produce maximum power.

-The Scottish island of "Gigha" puts on the market by the Scottish Government in August 2001, it was purchased by the community that created three companies that operate in the economy commercial sector of the island.

Among these, the Gigha Green Power manages the wind farm, is composed of $3 \mathrm{~V} 27$ wind turbines of $225 \mathrm{~kW}$ located at over $30 \mathrm{~m}$, with a production of $2.1 \mathrm{GWh}$ of electricity which covers $2 / 3$ of the total electricity needs of island (see Figure 4? O 5)

Wind turbines with the products $2.1 \mathrm{GW} /$ year, can avoid emissions in the atmosphere of over 900 TEP.

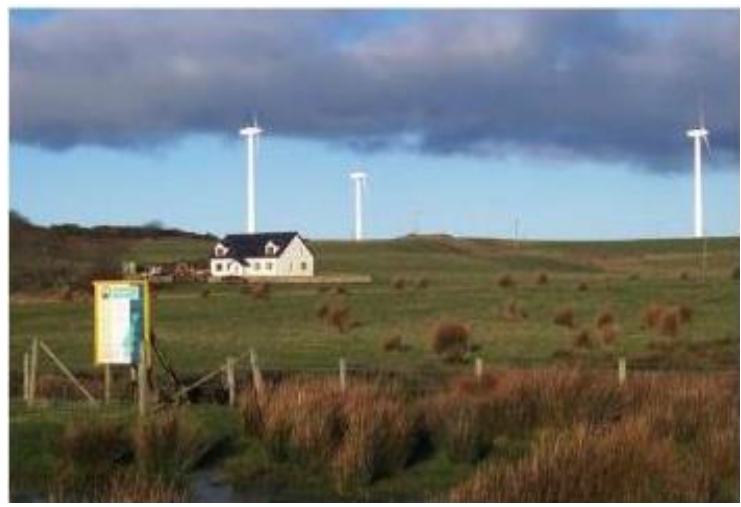

Figure 5. Wind turbine plant

Given the considerable energy production, net of operating costs, profit is of $£ 75,000$ a year.

The payback period, supported by the Community Energy Scotland, was calculated in 2-3 years

This resulted in a more than $73 \%$ energy savings.

It is currently covered $67 \%$ of the island's energy needs, thanks to the presence of wind turbines, as soon as the island of Gigha, will achieve $100 \%$ of energy independence, after will export energy.

For this purpose, it is considering the realization of an Anaerobic Digester (AD) and a Cogeneration Plant (CHP) as well as the possibility of expanding the wind farm from 3 to 5 wind turbines.

-The Scottish island "Muck", thanks to the presence of plants from renewable sources, produces electric energy by means of wind 6 turbines by $5 \mathrm{~kW}$, and $30 \mathrm{~kW}$ of solar panels connected to a $150 \mathrm{kw}$ storage battery. (see Figure 6).

This allows the local community is independent from central Thermal at diesel fuel, that by 40 years it provided electricity in the island. 
It 'also a storage system capable of covering 24 hours of blackout.

The island uses network at high voltage by $3.3 \mathrm{KV} 415 \mathrm{~V}$, with four transformers to it connected.

The structures of the island are linked to this network, it includes 20 domestic facilities, a guest house, a school, a community hall and 3 small workshops, all equipped with batteries for load control during periods when excess of wind power is using a control system frequency.

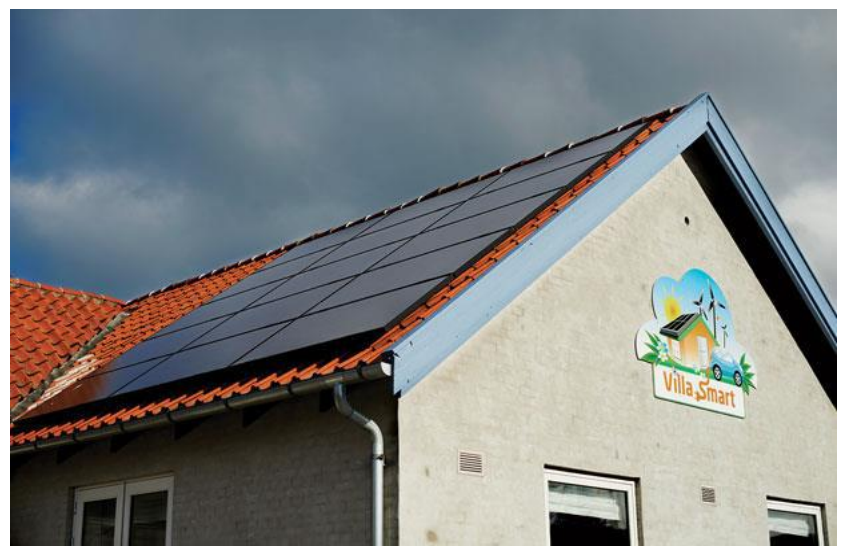

Figure 6. Photovoltaic installations in public housing

-In the island of "White", in the English Channel, the Government has decided to implement a system to make the island energetically self-sufficient through renewable sources by 2020 . The initiative, called Eco-island, plans to install 30 MW of capacity from renewable sources with 1300 solar roofs, technologies for the use of energy produced by tides, wind and geothermal energy.

Furthermore, the creation of a smart-grid, that has as its objective the reduction of the cost of the electricity bill of the inhabitants, through better management of demand, energy storage in batteries and projects for the production of hydrogen, are in fact in phase of realization two platforms connected to the hydrogen supply network (see Figure 7).

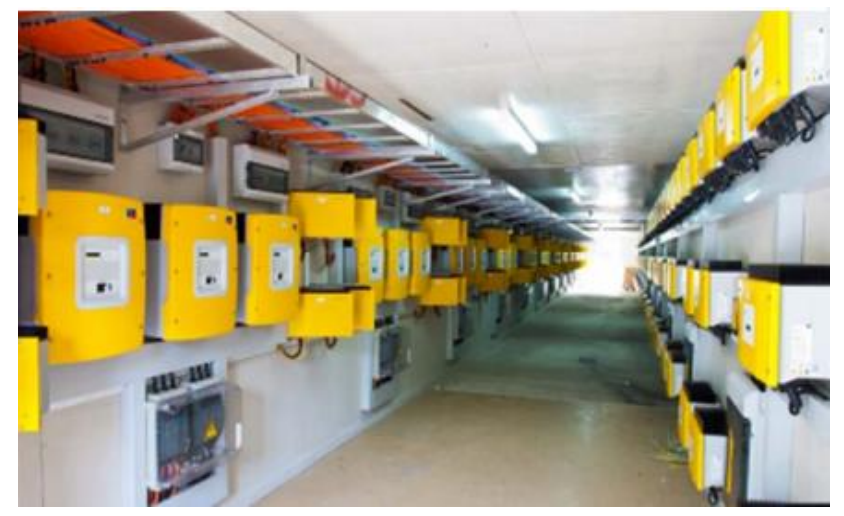

Figure 7. Storage systems

They will soon can use vehicles at hydrogen-powered, vans with hydrogen internal combustion engine and electric cars. It is also provided the exploitation of energy produced by the waves and tides. Is expected the creation of two areas where they will be tested a test device of $1 \mathrm{MW}$ and another, of up to $10 \mathrm{MW}$.

Then will follow the construction on land of a center for research, development and construction of turbines for power generation from the tides.

\subsection{The Island "Pellworm" in Germany}

The small island of "Pellworm", off the German North Sea coast, produces three times the electricity demand of its 1,200 inhabitants. This thanks to the presence of an energy system, consists of wind turbine 8 blades, which cover $70 \%$ of the local requirements. A solar power plant, with integrated the cogeneration plants for the remaining $30 \%$.

On days with slight winds the request is bypassed by a, biogas plant, that uses the methane coming from the processing of corn and sewage.

The system produces $22 \mathrm{GWh}$ of electricity yearly, compared to 7 million $\mathrm{kWh}$ needed for the local population. The excess part is sold to the local manager, thanks to the electrical connection present. At Pellworm currently are working for implementation of a storage system, considering if as well as lithium-oil technology can operate in a real context to make the smart-grid more and more 'intelligent'.

\subsection{The Caribbean Islands Bonaire and Aruba (Netherlands)}

-The island of "Bonaire", part of the BES islands in the Caribbean Sea, began installing the first wind turbines.

In its territory, they are operating 12 wind turbines, for a total of $11 \mathrm{MW}$ of power, which in moments of maximum wind, it provides up to $90 \%$ of the needs daily business electricity of the island and the about $45 \%$ of the needs annual.

The island is also equipped with a storage system from 6 MW, for provides electricity in low wind moments.

In addition, there is a $14 \mathrm{MW}$ power plant, can run on both conventional diesel and biofuels (see Figure 8).

In this it on which it is investing, cultivating algae in the island's salt pans, in order by in the future only use this biodiesel in the five generators.

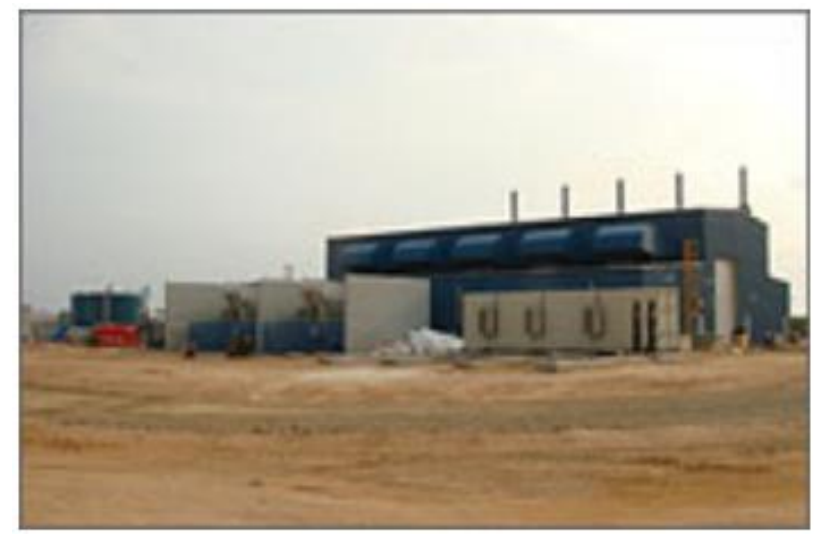

Figure 8. Central plug-in biofuels

The nearly 18,000 residents of Bonaire can then quickly take advantage of an electrical system with $100 \%$ Renewable, result of a perfect mix of wind power (45\%) and biodiesel $(55 \%)$. In addition, it was possible to experience a decrease of $10-20 \%$ of the cost in the bill for the electric supply as well as a saving of over 70,000 tons of $\mathrm{CO}_{2}$ released into the atmosphere.

-On the island of "Aruba" located in the Caribbean Sea, from June 2012, the Government has chosen to undertake an initiative to combat climate change, by converting the land 
into a prospect of use $100 \%$ renewable.

The $20 \%$ of its used electrical power is generated by the wind by means of 10 on-shore turbines for a total capacity of $30 \mathrm{MW}$, and are already being implemented several projects for the utilization of solar energy.

In 2015 a second wind farm with 26.4 MW capacity, has been completed that will use the latest generation of turbines. The island enjoys a very favorable position for installation of wind turbines, providing over 5,000 hours of wind per year; and are currently being study projects for other future new installations.

In the transportation, new low-emission technologies and use of biofuels as well as strategies to create a worldwide example of tourist and residential destination 'pedestrian' for tourists and residents are adopting. The island now adopts measures to rationalize the consumption of water for industries and households, by desalination of the water necessary for the totality of consumption and is moving towards a progressive replacement of all public lights with high efficiency LEDs. energy.

\subsection{The Island "Tokelau" in New Zealand}

-In the island of "Tokelau" since October 2012, the 1,500 inhabitants benefit from a photovoltaic plant stand-alone that makes these islands at the top spot in the world to produce $100 \%$ of its electricity from the sun. The old plant, consisting of three diesel generators that required more than 400 liters per day of diesel fuel and provided electricity only for 15-16 hours per day, have been replaced by three photovoltaic solar systems, one for each atoll, for a total of $1 \mathrm{MW}$ with inverter and batteries; in the event of cloudy days particularly the system would work with coconut oil instead of diesel.

The system required an investment of 7.5 million dollars from the Government of New Zealand, whose return, reducing the costs importing of fuel, evaluated in a short period, will avoid more than 12,000 tons of $\mathrm{CO}_{2}$ released into the atmosphere.

\section{THE ISLAND OF FAVIGNANA-CASE STUDY-}

In Italy ENEA has launched a series of pilot interventions for sustainable tourism on the territory of the Mediterranean islands, as part of the larger project "Eco-innovation Sicily".

The smaller islands in the Mediterranean are characterized by historical problems that have been exacerbated in recent decades because of a huge increase in summer tourism.

The Project "Eco-innovation Sicily" tends to favor the incentive of coordinated interventions in the field of environmental protection and development and promotion of innovative methodologies and technologies, in order to enable the development of the productive fabric in the South.

The Project, which has a duration of three years, has the following strategic objectives:

- to promote eco-sustainability of some significant productive sectors of the Sicilian Region, stimulating environmentally friendly business strategies to encourage its competitiveness through the implementation of a series of research, development, promotion, implementation of technological and methodological tools:

- to promote the awareness of enterprises, especially small and medium-sized, about the need to interact with each other creating a sharing system of the knowledge and skills available.

The project focuses on some significant productive sectors of the Sicilian Region:

- the recycling industry, and in particular in the field of Electronic Equipment and Plastic, with a pilot intervention for energy recovery and the recovery of valuable raw materials from waste from Electrical and Electronic Equipment (WEEE) and those coming from plastics, which also provides for the application, the first example in Italy, of the principles of the methodologies and tools of "industrial symbiosis";

- sustainable tourism, with a pilot project in the Egadi, in particular in the island of Favignana, developed into a "Smart Island" Optical

The island of Favignana, reported in Figure 9, belongs to the archipelago of the Egadi Islands, and is located $7 \mathrm{~km}$ from the west coast of Sicily, in the province of Trapani.

It is part of the Marine Protected Area Aegadian, established in 1991 and since 2001 managed on behalf of the Ministry by the City of Favignana.

The production and distribution of electricity is in operating concession at "S.E.A." Electricity Company of Favignana spa that serves 3,550 users.

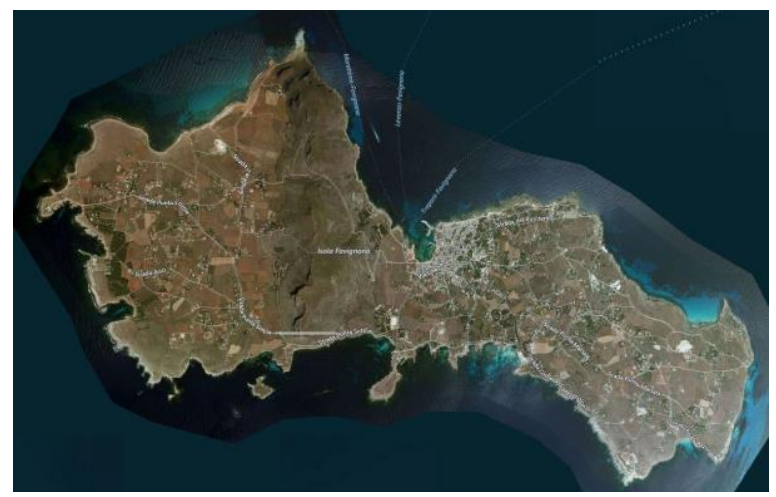

Figure 9. The Island of Favignana

The plant thermo-electricl, is constituted by generators, with installed capacity of $20 \mathrm{MW}$ (2011 production amounted to $14,000 \mathrm{MWh}$ ) fueled by diesel, supplied by tankers. In Fig.10 and Fig.11 are shown respectively for the months of January to June and July to December, and the Favignana's monthly daily average electricity consumption.

The heating in the housings, when it exists, is electric, such as the domestic hot water heating. For kitchens are used gas cylinders, transported by ship from Trapani.

Water is supplied through an underwater aqueduct connected to the city of Trapani, managed by EAS company, and through a desalination plant managed by Company "Siciliacque". In summer tanker ships and private vessels integrate the increased demand. On the island, there are numerous private wells, three storage tanks by $4.390 \mathrm{~m}^{3}$.

The municipal administration has decided to start energy project, as well as sustainable mobility, through a new strategy for the future of the island that provides, the construction of a new power plant of the type "zero emission", an LED lighting system and the installation of individual photovoltaic systems to be installed in the roofs of houses.

The local electric power company "Sea Favignana" in implementation of the energy strategy from the island "Favignana Zero Emissions," is planning in the near future, the replacement of the old plant Electric Central at combustion 
with a new environmentally friendly plant.

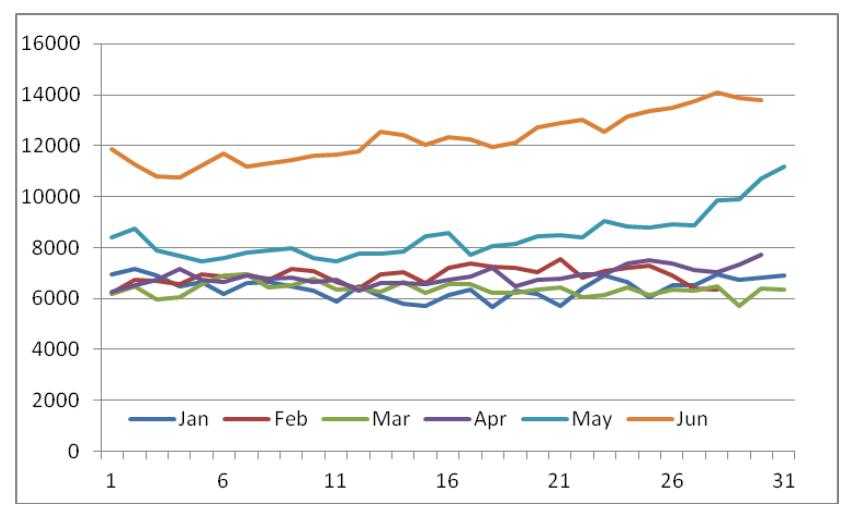

Figure 10. Average daily electrical consumption months 1-6

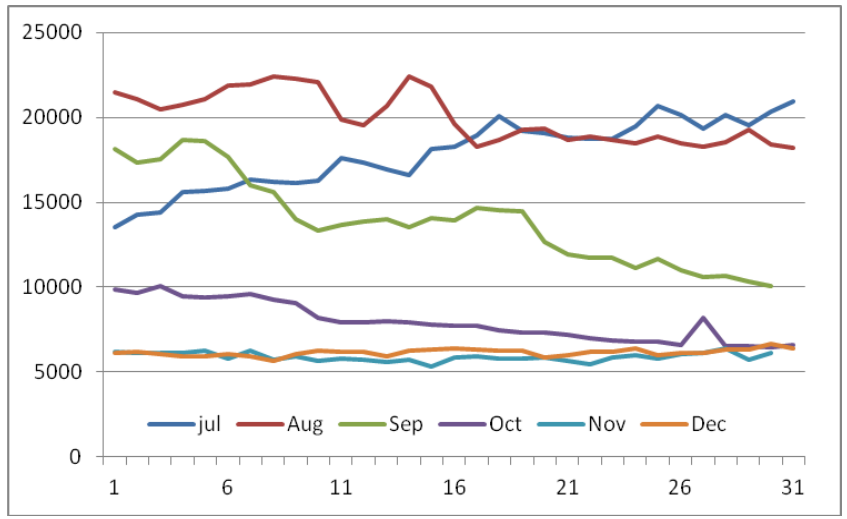

Figure 11. Average daily electrical consumption months 7-12

The project, implemented with the support of "The Green Consulting Group", and a number of companies partnership, provides a sustainable model with zero emissions, achieved through the transformation of the old central production, with a new hybrid plant at low environmental impact and high efficiency, with a power of $12 \mathrm{MW}$ of heat generator, powered by fuel oil.

This electric power plant, with the power of about 700 $\mathrm{MWh} /$ year, will ensure a reduction of $\mathrm{CO}_{2}$ emissions into the atmosphere of more than 500 tons.

The new plant will be built in a plot of land located over 500 meters from the coast, while the old power plant was located, approximately 100 meters from the coast.

The roof of the building will be entirely covered by a solar panel system capable of developing an output of $500 \mathrm{~kW}$, corresponding to $400 \%$ of currently installed photovoltaic power in the entire island.

The building of the old power plant will be reclaimed and restored to convert it into a public space with a social purpose with a lighting system powered by photovoltaic panels, as well as the crucifix, important symbol of Favignana, located at the top of the mountain, will be illuminated by a plant in LED powered by photovoltaic system. As for the "sustainable waste management" an innovative experimental plan, in line with European legislation, Italian and regional, integrated with the current "conferment station" already operating in the island, will be implemented. Under the Plan;

-the establishment of an ecological island of medium-sized and three small ecological islands;

-the installation of more "composters community" of innovative type for the treatment of organic waste and green fraction, with its on-site production of quality compost; -updating of the collection system for the entire island of Favignana, to be carried out, depending on the populated areas and the various users, with "door to door" system, and/or with road containers of "proximity".

-the realization of an advanced information system for the management of the system for collecting and charging waste.

It is also provided, the realization of a composting pilot plant for small communities. The composter belongs to the type at innovative technology, with a load capacity of up to $900 \mathrm{~kg} / \mathrm{month}$ and, thanks to a system with two separate chambers, enables the production of organic materia pretreated, in an average 40 days followed by about 30 days to get completely matured compost quality. The plant, being tested in laboratories Technical Unit of the Environmental Technology Center of ENEA Casaccia, will be installed in Favignana, and can serve a use of around 150 people. About, 15 home composters in the isolated houses will also associated at implant, in order to promote a virtuous circle of home composting: the integration of the composter and the promotion of home composting, that will create the conditions for starting of the island, especially during the winter; and an integrated sustainable waste management, that values the onsite organic waste through the production of quality compost.

The use of smart technologies "e-sensors" in the field of environmental monitoring, in residential buildings [11-29], hospitals and in the field of the historical buildings under protection and safeguard, will make achieve significant developments in the "smart city" and "smart islands", encouraging the growth of tourism and quality of life. The use of renewable energy in the new technologies and plant systems [30-35], will make a significant contribution to the sustainable development of Smarts Islands.

\section{ANALYSIS FEASIBILITY OF THE SYSTEM}

A technical-economic feasibility analysis, on the realization of a photovoltaic system in two different scenarios, that cover the energy needs required, is reported.

The first solution provides the realization of the plant by 4.67 MWp, with peak power from the photovoltaic plant such as to satisfy $50 \%$ of the total electricity demand of the island, allowing an initial annual production of 7,000 MWh.

The solar field is consisting of polycrystalline modules, with a southern exposure and a $35^{\circ}$ inclination, requires an area of $33,333 \mathrm{~m}^{2}$ and an initial investment of $€ 7,142,857.00$. The payback period is $\mathrm{n}$. 5 years and is characterized by a positive VAN to the twentieth, operation year of $€ 21,881,684$.

The second solution that provides the realization of photovoltaic plant, with peak of $6.66 \mathrm{MWp}$, to satisfy $70 \%$ of the total of the electricity island demand, it allowing an initial annual production of 9,800 MWh.

The solar field is consisting of polycrystalline modules, with a southern exposure and a $35^{\circ}$ inclination, requiring an area of 46,666 $\mathrm{m}^{2}$ and an investment of $€ 8,000,000.00$.

The payback period is 4 years and is characterized by a positive VAN to the twentieth year of $€ 32,007,219$ operation.

In Table 1 is reported the synthesis of the two cases analyzed in the two scenarios and the respective economic evaluations:

-Scenario 1 - Initial annual production of 7,000 MWh.

-Scenario 2 - Initial annual production of 9,800 MWh

In the two graphs of Fig.12 and Fig. 13 are shown the discounted cash flows relating to the above two scenarios. 
Table 1. Synthesis technical-economic, photovoltaic plant

\begin{tabular}{|c|c|c|c|c|c|c|c|c|}
\hline \multirow[t]{2}{*}{ Yes: } & \multicolumn{2}{|c|}{$\begin{array}{l}\text { Enegy Proused } \\
\text { by PV Piant } \\
\text { 5cenai } \\
50 \% \quad 70 \%\end{array}$} & \multicolumn{2}{|c|}{$\begin{array}{l}\text { Diese Oil Spaed by power } \\
\text { genering } \\
\text { 5cenai } \\
50 \% \quad 70 \%\end{array}$} & \multicolumn{2}{|c|}{$\begin{array}{l}\text { Cost Isaings diese Oil } \\
\text { Poner Geneasor } \\
\text { 5cenai } \\
50 \% \quad 70 \%\end{array}$} & \multicolumn{2}{|c|}{$\begin{array}{l}\text { Discountes cash fow } \\
\text { 5cenai } \\
50 \% \quad 70 \%\end{array}$} \\
\hline & MMniano & MMnianno & $n 0$ & anno & no & $n \times$ & Elano & ano \\
\hline 0 & 0 & 0 & $\cdot$ & & $\therefore$ & - & 42857 & 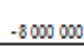 \\
\hline 1 & 70000 & & 265 & 3958971 & 9522 & 9331 & 73858 & 702 \\
\hline 2 & 6950 & 9702 & 272 & & 05684 & 958 & 8194 & 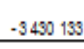 \\
\hline 3 & 682 & 9605 & 51520 & 28 & 6559212 & 497 & 2190370 & 11818 \\
\hline 4 & 67 & 9509 & 28005 & 59205 & 702147 & 83007 & - 574900 & 242 \\
\hline 5 & 6724 & 9414 & 4725 & 2226614 & 52531 & 2459544 & 1023694 & 3244639 \\
\hline 6 & 6657 & 9320 & 1677 & 194348 & 804405 & 526168 & 2605862 & 424178 \\
\hline 7 & 6590 & 9227 & & & 6781 & 00943 & 172127 & 582099 \\
\hline 8 & 6524 & 9134 & & & 28077 & 7931 & 2884 & 719018 \\
\hline 9 & 6459 & 904 & 909 & & 426 & 7198 & 99 & 55549 \\
\hline 10 & 6395 & 89 & 91770 & 78 & 227721 & 8811 & 79712 & 3952283 \\
\hline 11 & & & 69052 & 67793 & 2087742 & 22840 & 10286655 & 009943 \\
\hline 12 & & & 18154 & 3097415 & 14953 & 56 & 11779853 & 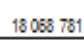 \\
\hline 13 & 6205 & $86 \%$ & 2126672 & 2977341 & 2213106 & 433 & 13259725 & 201096007 \\
\hline 14 & 6143 & 8600 & 05406 & 68 & 2278675 & 190146 & 14726662 & 2133105 \\
\hline 15 & 6081 & 8514 & 4352 & 92 & 2345124 & 284574 & 16181128 & 41996 \\
\hline 16 & 6020 & 8429 & 3508 & 68911 & 15570 & 3951798 & 17623453 & 251297 \\
\hline 17 & 5960 & 83 & 2042873 & 22 & 87071 & 3451899 & 19054078 & 28104034 \\
\hline 18 & 50.01 & 8001 & 44 & & 25006888 & 3584963 & 158 & 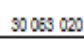 \\
\hline 19 & 5842 & 8178 & 2200 & & 6484 & 3091018 & 1881684 & $32007 / 2$ \\
\hline
\end{tabular}

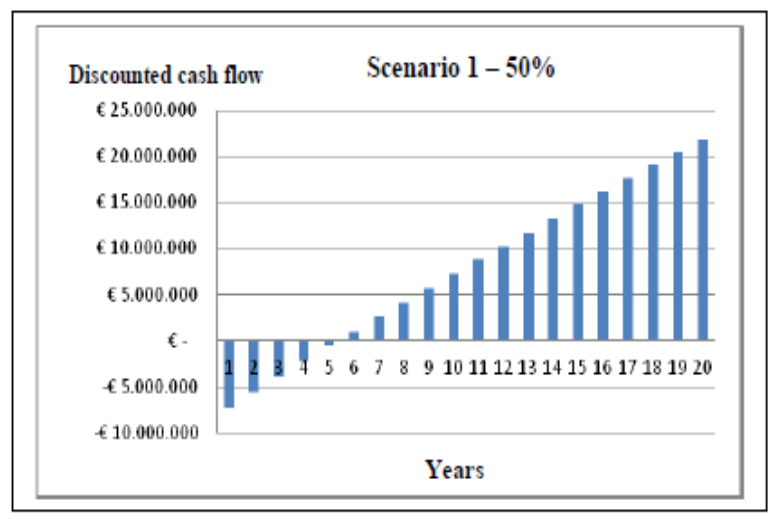

Figure 12. Discounted cash flow-50\% Scenario

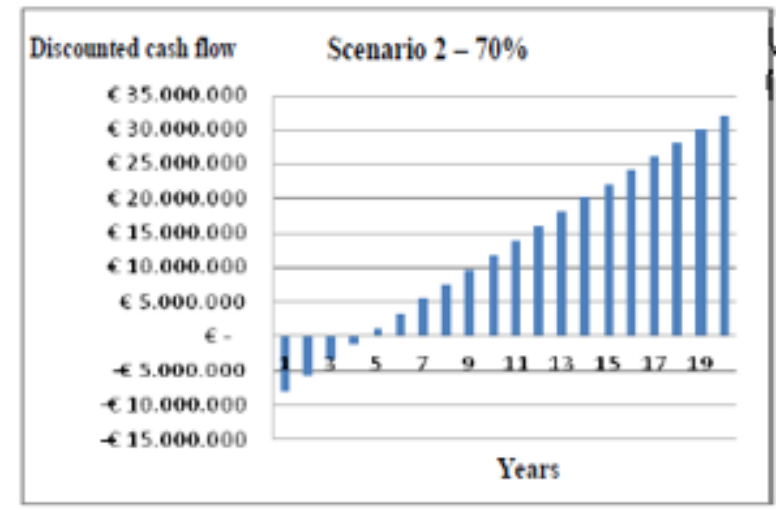

Figure 13. Discounted cash flow-70\% Scenario

As can be seen from Table 1, and by the two graphs of Fig.
12 and Fig. 13, the investment cash flow, becomes positive from five years for scenario 1 , while the scenario 2 , reaches the positivity after only 4 years. It is also noted that the scenario 2 shows over the years a saving equal to $33 \%$ greater than that obtainable with the scenario 1 .

\section{CONCLUSIONS}

The Energy choices adopted in the European continent, by the "Smart Islands", show some examples of how the proper use of renewable energy sources (RES), (solar, wind, biomass, wave, etc.), can help to reduce dependence by the fuels exogenous fossils, and gas emissions greenhouse, due to the energy emission and global warming. The relation presented shows how the issue has been addressed in many European islands, located at north to south of the continent, and in some Caribbean islands and New Zealand. The "Sea Favignana", local electric power company, in implementation of the energy strategy from the island "Favignana Zero Emissions", is planning for the near future, the replacement of the old plant Electric at combustion, with a new sustainable electric plant. Measures for a sustainable energy are underway on the island, the project being implemented with the support of "The Green Consulting Group" and a number of companies partnership; the project expected the replacement of old plant production, with a new hybrid plant (photovoltaic-fuel oil) with low environmental impact and high efficiency of $12 \mathrm{MW}$ of power.

The new facility of electricity, and a sustainable energy planned intervention (plastic recycling, photovoltaic and mobility), can ensure a reduction of $\mathrm{CO}_{2}$ emitted in more than 500 tons atmosphere, as proposed by the Kyoto Protocol, and by commitments made by European Community.

\section{REFERENCES}

[1] Cannistraro G., Cannistraro M., Restivo R. (2012). The "Smart City", a new model of contemporary city: A case study of a sustainable neighborhood, Environment and Energy, No. 1, pp. 73-85.

[2] Giffinger R., Fertner C., Kramar H., Kalasek R., Pichler-Milanovic N., Meijers E. (2007). Smart cities. Ranking of European medium-sized cities, Final Report, Edited by the Centre of Regional Science, Vienna UT, www.smart-cities.eu

[3] Forghieri C., La Smart City al servizio del cittadino. I papers scientifici di SCE 2013, Smart Innovation http://smartinnovation.forumpa.it/story/75036/lasmart-city-al-servizio-del-cittadino

[4] Renewable Energies for Remote Areas and Islands (Remote), p. 18-22, IEA-RETD, April 2012. http://iearetd.org/wp-content/uploads/2012/06/IEA-RETD

[5] U.S. Energy Information Administration, Electric Power Monthly, July 2015, Http://www.eia.gov/ electricity/ monthly/pdf/epm.pdf

[6] Enslin J. Grid Impacts and Solutions of Renewables at High Penetration Levels, Quanta Technology, http://quanta-technology.com/sites/default/files/docfiles/Grid-Impactsand-Solutions-of-RenewablesExecutive-Summary.[8pdf

[7] San Martin J.I., Zamora I., San Martin J.J., Aperribay V., Eguia P. (2011). Energy storage technologies for electric applications, International Conference on 
Renewable Energy and Power Quality,

[8] Wind for Microgrids, Northern Power Systems, 2013, http://www.northernpower.com/wp-Content/uploads/ 2014/06/Wind-for-Microgrids-Application-N-Amer.pdf

[9] The Ashden Awards for sustainable energy, Ashden Awards Case Study Isle of Eigg Heritage Trust, Scotland, May 2010. 8 L. Murray, "How Richard Branson bought Necker Island," Virgin Entrepreneur, 2015, http://www.virgin.com/entrepreneur/howrichard-branson-bought-necker-island

[10] Schwartz A. (2009). Antarctica turning to solar, wind power, CleanTechnica,Jan. 2009, http://cleantechnica.Com/2009/01/ 22/antarcticaturning-to-solar-wind-power/

[11] Cannistraro G., Cannistraro M., Restivo R. (2015). Some observations on the radiative exchanges influence on thermal comfort, Rectangular Open-Space Environments, Vol. 33, pp. 79-84. DOI: $\underline{10.18280 / \mathrm{ijht} .330213}$

[12] Cannistraro G., Cannistraro M., Restivo R. (2015). The local media radiant temperature for the calculation of comfort in areas characterized by radiant surfaces, Vol. 33, pp. 115-122. DOI: 10.18280/ijht.330116

[13] Cannistraro G., Cannistraro M. (2016). Hypothermia risk, monitoring and environment control in operating rooms, IJH\&T, Vol. 34, No. 2, pp. 165-171. DOI: $\underline{10.18280 / \mathrm{ijht} .340202}$

[14] Cannistraro M., Leonardi S.G., Aloisio D., Patti E., Pace C., Khalaf W., Donato N., Neri G. (2013). Development of electronic-nose technologies for biomedical applications, Intern. Congress XVII Annual Conference AISEM, Brescia.

[15] Cannistraro M., Lorenzini E. (2016). The applications of the new technologies "E-sensing", Hospitals, Vol. 34, No. 4, pp. 551-557. DOI: $10.18280 /$ ijht.340401

[16] Cannistraro M., Bernardo E. (2017). Monitoring of the indoor microclimate in hospital environments - a case study the Papardo hospital in Messina, Congresso AIGE-IIETA 2017, 11-12 Giugno 2017 Genova.

[17] Salata F., Golasi I., Petitti D., de Lieto Vollaro E., Coppi M., de Lieto Vollaro A. (2017). Relating microclimate, human thermal comfort and health during heat waves: An analysis of heat island mitigation strategies through a case study in an urban outdoor environment, Sustainable Cities and Society, Vol. 30, pp. 79-96. DOI: $\underline{\text { 10.1016/j.scs.2017.01.006 }}$

[18] Cannistraro G., Cannistraro A., Cannistraro M., Galvagno A., Trovato G. (2016). Analysis of the air pollution in the Urban center of four Sicilian cities, International Journal of Heat \& Technology, Vol. 34, No. 2, pp. S219-225. DOI: 10.18280/ijht.34S205

[19] Cannistraro G., Cannistraro M., Cannistraro A. (2016). Evaluation of the sound emissions and climate acoustic in proximity of one railway station, International Journal of Heat \& Technology, Vol. 34, No. 2, pp. S589-596. DOI: $10.18280 /$ ijht.34S255

[20] D'Orazio A., Fontana L., Salata F. (2011). Experimental study of a semi-passive ventilation grille with a feedback control system, Review of Scientific Instruments, Vol. 82, No. 8, p. 118. DOI: $\underline{10.1063 / 1.3626793}$

[21] Intini F., Rospi G., Cardinale N., Köhtz S., Dassisti M. (2016). Life cycle assessment of Italian residential windows: Sensitivity of analysis, International Journal of Heat \& Technology, Vol. 34, Sp. 2, pp. S235-S241. DOI: $10.18280 /$ ijht.34S207

[22] Marino C., Nucara A., Pietrafesa M. (2015). Mapping of the indoor comfort conditions considering the effect of solar radiation, Solar Energy, Vol. 113, pp. 63-77. DOI: $10.1016 /$ j.solener.2014.12.020

[23] Marino C., Nucara A., Pietrafesa M. (2017). Thermal comfort in indoor environment: Effect of the solar radiation on the radiant temperature asymmetry, Sol. Energy, Vol. 144, pp. 295-309. DOI: 10.1016/j.solener.2017.01.014

[24] Cardinale N., Stefanizzi P., Rospi G., Augenti V. (2010). Thermal performance of a mobile home with light envelope, Building Simulation, Vol. 3, pp. 331338. DOI: $\underline{10.1007 / \mathrm{s} 12273-010-0017-0}$

[25] Salata F., Alippi C., Tarsitano A. Golasi I. Coppi M. (2015). A first approach to natural thermo ventilation of residential buildings through ventilation chimneys supplied by solar ponds, Sustainability (Switzerland), Vol. 7, No. 7, pp. 9649-9663. DOI: 10.3390/su7079649

[26] Cannistraro M., Cannistraro G., Piccolo A., Restivo R. (2013). Potential and limits of oxidative photo catalyses and possible applications in the field of cultural heritage, Advanced Materials Research, Vol. 787, pp. 111-117.

[27] Cannistraro G., Cannistraro M., Restivo R. (2013). Messina's historical buildings after the earthquake of 1908: Energy and environmental analysis through a global screening methodology, Vol. 31, No. 2, pp. 155, 158. DOI: $10.18280 /$ ijht.310221

[28] Cardinale T., Rospi G., Cardinale N. (2014). The influence of indoor microclimate on thermal comfort and conservation of artworks: the case study of the Cathedral of Matera (South Italy). Energy Procedia, vol. 59, p. 425-432, DOI: $\underline{10.1016 / \text { j.egypro.2014.10.398 }}$

[29] Cannistraro G., Cannistraro M., Cannistraro A., Galvagno A., Trovato G. (2015). Evaluation of the convenience of a citizen service district heating for residential use. A new scenario introduced by high efficiency energy system, $I J H \& T$, Vol. 33, No. 4, pp. 167-172. DOI: $10.18280 /$ ijht.330421

[30] Cannistraro G., Cannistraro M., Galvagno A., Trovato G. (2016). Evaluation technical and economic the integrations of co-trigeneration systems in the dairy industry, Vol. 34, No. 2, pp. S332-S336. DOI: 10.18280/ijht.34S220

[31] Cannistraro G., Cannistraro M., Galvagno A., Trovato G. (2016). Reduced the demand of energy cooling in the CED, centers of processing data, with use of Freecooling systems, Vol. 34, No. 3, pp. 489-502. DOI: 10.18280/ijht.340321

[32] Cucumo M., Ferraro V., Kaliakatsos D., Mele M., Barci G. (2016). Performance of a fields of geothermal probes to support the air conditioning plant of a public building powered by water/water heat pumps, Vol. 34, No. 2, pp. S535-S544. DOI: $10.18280 /$ ijht.34S248

[33] Cucumo M., Ferraro V., Kaliakatsos D., Mele M., Nicoletti F. (2016). Calculation model using finite difference method for energy analysis in a concentrating solar plant with linear Fresnel reflectors, Vol. 34, No. 2. DOI: 10.18280/ijht.34S221

[34] Kaliakatsos D, Cucumo M, Ferraro V, Mele M, Cucumo S, Miele A. (2017). Performance of 
dishstirling CSP system with dislocated engine, Internat. Journal of Energy and Envir. Eng, Vol. 8, No. 1, pp. 65-80. DOI: $10.1007 / \mathrm{s} 40095-015-0183-\mathrm{z}$

[35] Piccolo A., Siclari R., Rando F., Cannistraro M. (2017).
Comparative performance of thermoacoustic heat exchangers with different pore geometries in oscillatory flow. Implementation of Experimental Techniques, Applied Science, Vol. 7, p. 784. 